\title{
Initial development of upland rice plants inoculated with the MAY12 strain of Azospirillum spp.
}

\section{Marivaine da Silva Brasil ${ }^{*}$ (iD) Mayara Silva Torres de Souza ${ }^{1}$ (iD Salomão Lima Guimarães ${ }^{2}$ (iD) Sergio Luiz Koswoski Junior ${ }^{2}$ (iD) Matheus Wimkler Alvarenga Batistela² (iD)}

${ }^{1}$ Universidade Federal do Mato Grosso do Sul (UFMS), 79304-902, Corumbá, MS, Brasil. E-mail: marivaine@hotmail.com. *Corresponding author. ${ }^{2}$ Universidade Federal de Rondonópolis (UFR), Rondonópolis, MT, Brasil.

\begin{abstract}
The purpose of this study was to evaluate the contribution of the inoculation of the strain Azospirillum MAY12 to the development of rice plants of the cultivar BRS Esmeralda. A completely randomized experiment was performed in a greenhouse, with 8 treatments and 6 repetitions, namely, commercial inoculant (CI) containing strains of Azospirillum brasilense ABV5 and ABV6 (T1), MAY12 (T2), nitrogen control with $50 \mathrm{mg}$ of $\mathrm{N}$ or full dose (T3), $\mathrm{CI}+30 \%$ of $\mathrm{N}$ (percentage referring to full dose) (T4), $C I+60 \% \mathrm{~N}(\mathrm{T5}), \mathrm{MAY} 12+30 \% \mathrm{~N}(\mathrm{T6}), \mathrm{MAY} 12+60 \%$ $N(T 7)$ and absolute control (T8). There was a significant increase in the fresh and dry mass of the shoot and roots, height, root volume, and the number of tillers and leaves of plants with the MAY12 inoculation (with and without $N$ added) compared to T8. Treatments containing MAY12 + $N$ increased the total dry mass by 2920 compared to T8, matching the T3 yield. The inoculation of MAY12 in isolation was as efficient as the application of the full dose of $N$, resulting in an increase of $\sim 115 \%$ in height and $373 \%$ in root volume of the plants compared to T8. The MAY12 strain demonstrated good performance in the development of the cultivar, which was comparable to the CI in the variables tested. Therefore, inoculation with the MAY12 strain is promising for the partial reduction of nitrogen fertilizers in upland rice cultivation.
\end{abstract}

Key words: Oryza sativa L., diazotrophic bacteria, plant growth-promoting bacteria.

Desenvolvimento inicial de plantas de arroz de terras altas inoculadas com a estirpe MAY12 de Azospirillum spp.

RESUMO: O objetivo deste trabalho foi avaliar a contribuição da inoculação da estirpe de Azospirillum MAY12 no desenvolvimento de plantas de arroz da cultivar BRS Esmeralda. Foi realizado um experimento inteiramente casualizado em casa de vegetação, tendo oito tratamentos e seis repetições: inoculante comercial (IC) contendo as estirpes de Azospirillum brasilense AbV5 e AbV6 (T1), MAY12 (T2), testemunha nitrogenada com $50 \mathrm{mg}$ de $\mathrm{N}$ ou dose cheia (T3), IC $+30 \%$ de $\mathrm{N}$ (percentual referente à dose cheia) (T4), IC $+60 \%$ de $N$ (T5), MAY12 + 30\% de N (T6), MAY12 + 60\% de N (T7) e testemunha absoluta (T8). Houve aumento significativo da massa fresca e seca da parte aérea e de raízes, altura, volume de raizes e do número de perfilhos e de folhas das plantas com a inoculação de MAY12 (com e sem adição de N) em relação a T8. Os tratamentos contendo MAY12 + N aumentaram em torno de $920 \%$ a massa seca total em relação a T8, equiparando-se ao rendimento T3. A inoculação de MAY12, isoladamente, foi tão eficiente quanto a aplicação da dose cheia de $N$ para o aumento em torno de $115 \%$ da altura e de $373 \%$ do volume de raizes das plantas em relação a T8. A estirpe MAY12 apresentou bom desempenho no desenvolvimento da cultivar equiparando-se com o IC nas variáveis testadas. Portanto, a inoculação com a estirpe MAY12 mostra-se promissora para a redução parcial de fertilizantes nitrogenados no cultivo de arroz de terras altas.

Palavras-chave: Oryza sativa L., bactérias diazotróficas, bactérias promotoras de crescimento de plantas.

\section{INTRODUCTION}

Rice (Oryza sativa) originated in Asia and is one of the most widely produced cereals in the world, responsible for feeding $\sim 50 \%$ of the world's population (KUMAR \& LADHA, 2011). Brazil is one of the leading rice producers, with production representing $\sim 1.6 \%$ of the world total, ranking 9th, only behind Asian countries (SILVA, 2014). As per data from Conab (2019), the total rice area of the 2018/2019 harvest was 1716.9 thousand hectares, of which $78.6 \%$ (1350 thousand hectares) corresponded to irrigated rice, and the remaining $21.4 \%$ (366.9 thousand hectares) corresponded to the cultivation of upland rice.

ARANTES (2013) reported that upland rice, commonly known as dryland rice, is grown using only water from rainfall, and is the reality for small farmers in poor regions of the world such as Asia, Africa and Latin America. This is not only because of a lack of resources for irrigated planting but also because of the high demand for rice. 
Therefore, dryland rice, as one of the alternative forms of production, is used to meet this demand. Thus, technologies focused on this type of cultivation are extremely important.

$\mathrm{N}$ deficiency is one of the primary limiting factors to the production of upland rice worldwide. Nitrogen deficiency in upland crops is related to the high cost of nitrogenated fertilizer. Other factors, such as leaching, volatilization, denitrification and erosion, result in low efficiency of nitrogen use in the crop (FAGERIA \& BALIGAR, 2005; FAGERIA et al., 2010), as well as polluting the environment, contaminating water bodies and increasing greenhouse gas emissions. An alternative to the use of chemical inputs, to minimize the environmental impacts and mitigate the cost of agricultural production is the use of inoculants, i.e., products that contain microorganisms beneficial to plant development.

Inoculants containing selected bacteria of the genus Azospirillum have been extensively marketed and their use has shown benefits in the growth, development and productivity of plants under controlled field conditions (CÁSSAN \& DIAZ ZORITA, 2016). The benefits of Azospirillumcontaining inoculants for plants are primarily attributed to their ability to fix atmospheric nitrogen, increasing the contribution of $\mathrm{N}$ to the associated plant, and to synthesize phytohormones, in particular indole acetic acid (IAA), which promotes root growth and helps improve water and nutrient absorption (HUNGRIA et al., 2011; FUKAMI et al., 2018). Other characteristics already described for Azospirillum that benefit the plants are siderophore production, phosphate solubilization, and the induction of biotic and abiotic stress tolerance mechanisms in plants (BASHAN \& DE BASHAN, 2010; FUKAMI et al., 2018). According to BASHAN \& DE BASHAN (2010), multiple mechanisms of Azospirillum can act in sequential or accumulative patterns, promoting plant growth. Hence, certain strains of the genus are called plant growth-promoting bacteria (PGPB).

In Brazil, a combination of strains AbV5 and AbV6 of Azospirillum brasilense is used to formulate eleven products primarily recommended for corn, wheat and rice crops (CÁSSAN \& DIAZ ZORITA, 2016). Inoculation of AbV5 and AbV6 strains resulted in increased yields of up to $26 \%$ in corn and $31 \%$ in wheat. This was correlated not only with the increase in $\mathrm{N}$ but also in other nutrients such as phosphorus and potassium (HUNGRIA et al., 2010). Increased root growth, taller plants and greener coloration were observed as effects of inoculation because of the increased chlorophyll content (HUNGRIA et al., 2010; HUNGRIA et al., 2011). More recently, inoculation of AbV5 and AbV6 reduced $\mathrm{N}$ fertilization rates in corn and wheat plants by $25 \%$ (FUKAMI et al., 2016). Thus, the results showed increases in crop yield and substantial reductions in the use of nitrogen fertilizer when Azospirillum was used as an inoculant. However, the responses to Azospirillum inoculation in field experiments are inconsistent because of factors such as edaphoclimatic conditions, interactions with soil biota, inoculation techniques, and crop management practices (REIS, 2007; CÁSSAN \& DIAZ ZORITA, 2016). It is essential to consider these factors and to select the most promising strains for the success of inoculation technology.

Promising growth-promoting characteristics, such as high IAA production in vitro, and the ability to fix atmospheric nitrogen (SOUZA et al., 2017) and to solubilize phosphate (unpublished data), led to the selection of the MAY12 strain of Azospirillum for use in greenhouse inoculation experiments. This strain demonstrated benefits on the development of three forage grasses (SOUZA et al., 2017) and corn (GALEANO et al., 2019), highlighting its potential as a plant growth-promoting bacteria (PGPB). In this context, this study evaluated the contribution of inoculation of the Azospirillum MAY12 strain in the development of rice plants of the cultivar BRS Esmeralda, in a greenhouse experiment.

\section{MATERIALS AND METHODS}

The experiment was conducted in a greenhouse at the Instituto de Ciências Agrágrias e Tecnologias of the Federal University of Rondonópolis - UFR (16 $27^{\prime} 48^{\prime \prime}$ South latitude, $54^{\circ} 34^{\prime} 45^{\prime \prime}$ West longitude and $284 \mathrm{~m}$ altitude) from April to July 2018. The UFR is located in the municipality of Rondonópolis, MT, Brazil.

The experimental design was completely randomized with eight treatments and six replications: commercial inoculant (CI) containing Azospirillum brasilense strains AbV5 and AbV6 (T1), Azospirillum MAY12 strain (T2), nitrogen control with $50 \mathrm{mg} \mathrm{dm}^{-3}$ $\mathrm{N}$ in the form of urea or full dose (T3), $\mathrm{CI}+30 \% \mathrm{~N}$ (percentage referring to full) (T4), CI $+60 \% \mathrm{~N}$ (T5), MAY $12+30 \% \mathrm{~N}(\mathrm{~T} 6)$, MAY $12+60 \% \mathrm{~N}$ (T7) and absolute control (T8).

The soil used in the experiment was collected in a Cerrado area of the UFR at a depth of 0-20 cm and classified as dystrophic red oxisol (EMBRAPA, 2006). The chemical characteristics of the soil were: $\mathrm{pH}, 4.0$ in $\mathrm{CaCl}_{2}$; organic matter, $27.1 \mathrm{~g} \mathrm{dm}^{-3} ; \mathrm{P}, 1.4 \mathrm{mg} \mathrm{dm}^{-3}$; 
$\mathrm{K}+, 23 \mathrm{mg} \mathrm{dm}{ }^{-3} ; \mathrm{Ca}^{2+}, 0.4 \mathrm{mg} \mathrm{dm}{ }^{-3} ; \mathrm{Mg}^{2+}, 0.2$ cmolc $\mathrm{dm}^{-3}$; H, $5.4 \mathrm{cmolc} \mathrm{dm}^{-3}$; Al, $0.8 \mathrm{cmolc} \mathrm{dm}^{-3}$; V (base saturation), 9.7\%; CEC (cation exchange capacity), 6.8 cmolc dm${ }^{-3}$ and SB (sum of bases), $0.7 \mathrm{cmolc} \mathrm{dm}^{-3}$.

Using the results of the analysis, the soil was submitted to liming to achieve $60 \%$ base saturation. Soil was placed in $5 \mathrm{~kg}$ plastic bags, mixed with the limestone, and then water was added to promote the reaction. The bags were sealed and incubated for 30 days. After the correction period, the soil was transferred to black plastic pots with $1 \mathrm{dm}^{3}$ capacity, and then fertilized with phosphate $\left(\mathrm{P}_{2} \mathrm{O}_{5}\right)$ and potassium $\left(\mathrm{K}_{2} \mathrm{O}\right)$ at 200 and $80 \mathrm{mg} \mathrm{dm}^{-3}$, respectively.

The cultivar selected for planting was BRS Esmeralda, recommended for upland cultivation. It is characterized by high yield and grain quality, and is moderately resistant to most diseases and water stress (CASTRO et al., 2014).

Ten seeds of the cultivar BRS Esmeralda were sown per pot, placing each seed in an individual opening, $3 \mathrm{~cm}$ deep. After germination - which occurred 3 days after sowing - the plants were thinned to leave two plants per pot, and then the inoculation was applied. For this, the MAY12 strain isolated from the native grass of the Mato Grosso do Sul Pantanal, Hymenachne amplexicualis (SOUZA et al., 2017), was used. MAY 12 belongs to the culture collection of the microbiology laboratory of the Pantanal Campus of the Federal University of Mato Grosso do Sul. It was preserved in an Eppendorf tube containing distilled water + glycerol in a ratio of $1: 1$. An aliquot of 500 microliters was removed and added to vials containing $100 \mathrm{~mL}$ of DYGS culture medium (RODRIGUES NETO et al., 1986). The vials were then placed on a stirring table with constant stirring at 100 revolutions per minute at $30^{\circ} \mathrm{C}$ for $48 \mathrm{~h}$. The commercial inoculant used was composed of the strains ABV5 and ABV6 of Azospirillum brasilense at a concentration of $1.0 \times 10^{9} \mathrm{CFU} \mathrm{mL} \mathrm{mL}^{-1}$. Both the MAY12 strain and the commercial inoculant were applied near the root system of each plant, in a volume of $5 \mathrm{~mL}$. Bacterial cell concentration was $1.0 \times 10^{9}$ $\mathrm{CFU} \mathrm{mL}^{-1}$, adjusted according to the methodology described by FERREIRA et al. (2003).

Nitrogen fertilization was applied following the recommendation of $50 \mathrm{mg} \mathrm{dm}^{-3}$ of N (GUIMARÃES et al., 2010), in the form of urea via solution, and for inoculated treatments the proportions of $0 \%, 30 \%$ and $60 \%$ were used in relation to the recommendation, according to the determined treatments. The nitrogen was applied when the plants reached $10 \mathrm{~cm}$ in height.
For the experiment, $60 \%$ of the moisture retention capacity was maintained in each pot. The capacity of the pot was established following a method applied by BONFIM-SILVA et al. (2011). The pots were manually irrigated with distilled water, twice a day, using the gravimetric method, to reduce water stress to the plant as much as possible by maintaining the required moisture level. The environmental conditions of the greenhouse were as follows: average temperature of $30{ }^{\circ} \mathrm{C}$, relative air humidity of $51 \%$, and the greenhouse was enclosed with 0.15 -mm-thick plastic.

The treatments were evaluated by the following parameters: Falker chlorophyll index, height, number of tillers, number of leaves, fresh and dry mass of the roots and shoot, total dry mass and root volume of the rice plants. The chlorophyll index was determined using a ChlorophyLog ${ }^{\circledR}$ Falker chlorophylometer. Two readings were taken per pot, one for each plant, in the middle of the last fully expanded leaf, establishing an average per pot. A total of five evaluations were performed: the first at 30 days after the emergence (DAE) of the plants and the others at intervals of $\sim 10$ days apart. The height was measured from the base to the node of the flag leaf of the highest profile using a graduated ruler. The number of tillers was obtained by adding the number present in each plant per experimental unit. The height and number of tillers were determined at 36,57 and 72 days after sowing (DAS). At the end of the experiment (70 DAE), fresh root mass $(\mathrm{g})$, fresh shoot mass $(\mathrm{g})$, dry root mass (g), dry shoot mass (g) and total dry mass $(\mathrm{g})$ and root volume were evaluated. For this, the roots and shoot of the plants were first separated. The roots were washed and air-dried, then both the roots and the shoot were weighed on an analytic scale to determine the fresh mass. After obtaining data for fresh mass, the roots and shoot were placed in paper bags and dried at $65^{\circ} \mathrm{C}$ to constant mass. The materials were then weighed to determine the dry mass. The total dry mass was obtained by adding the results of the dry root and shoots mass. Root volume was determined by the increase in water volume in $\mathrm{cm}^{3}$ after immersion of samples in test tubes containing a known volume of water $(300 \mathrm{~mL})$. The data obtained were submitted to variance analysis and comparison of means by the Tukey test at 5\% significance using SISVAR statistical software (FERREIRA, 2011).

\section{RESULTS AND DISCUSSION}

The Falker chlorophyll index (FCI) data are recorded in table 1 , where the mean FCI per

Ciência Rural, v.51, n.12, 2021. 
treatment and its respective reading interval are shown. Nitrogen treatments (T3, T4, T5, T6 and T7) presented the highest mean chlorophyll content; however, in the fourth and fifth FCI readings, there was no significant difference between any of the nitrogen-containing treatments compared to the absolute control (Table 1). Treatments inoculated with the addition of nitrogen, either with the commercial inoculant or with MAY12, presented means that were statistically similar to that of the nitrogen control (T3) in four of the five readings because T3 only had the highest mean FCI (Table 1) in the third reading. In other words, in most of the FCI readings, the yields were the same as that of the full dose used in T3.

Generally, the chlorophyll content correlates positively with the $\mathrm{N}$ content of the leaves because $\mathrm{N}$ is a component of its molecule (CARVALHO et al., 2012). CABANGON et al. (2011) observed a good correlation between the $\mathrm{N}$ content and the reading of the chlorophyll content of rice leaves analyzed by the SPAD chlorophylometer, suggesting that the inoculation of Azospirillum in this study may have contributed to the contribution of $\mathrm{N}$ in the leaves and, as a consequence, to the greater accumulation of chlorophyll.

There was no statistical difference between the mean FCIs of treatments containing only the commercial inoculant or MAY12 or in relation to the absolute control in all readings (Table 1). To summarize, these results confirmed that MAY12, under the conditions tested, can be used as an alternative source of inoculation as it can yield results similar to those of the commercial inoculant. Similar results were obtained in the research of JARDIM et al. (2018) in which the relative chlorophyll index variable did not differ statistically in treatments with commercial inoculant (with Azospirillum brasilense strains AbV5 and AbV6) and non-inoculated treatment in irrigated rice cultivation of the 2015/2016 harvest in Capão do Leão, RS. However, the application of doses of 60,120 and $180 \mathrm{~kg} \mathrm{ha}^{-1}$ of nitrogen to rice promoted increases of $2.8 \%, 3.4 \%$ and $10.3 \%$, respectively, in the relative leaf chlorophyll index compared to the absolute control.

The production of fresh and dry mass of the roots and shoot was significantly stimulated $(\mathrm{p}<$ 0.05 ) by the inoculation and application of different doses of $\mathrm{N}$, alone or in combination because the mass values of the treatments were higher than that of the absolute control (Table 2). The nitrogen control had the highest mass values. However, for the most part, it did not statistically differ from the other treatments containing $\mathrm{N}$ doses (Table 2). Because the nitrogen control obtained the highest values of dry mass of the shoot and roots, the treatments that received the applications in different doses yielded mass values of $\sim 86 \%$ and $74 \%$ of the total, respectively. This demonstrated that inoculation helped increase mass because nitrogen doses contained a maximum of $60 \%$ of the $\mathrm{N}$ applied in the nitrogen control (Table 2). It also showed that inoculation of plant growth-promoting bacteria (PGPB) is an alternative to decrease the use

Table 1 - Falker chlorophyll index in rice plants, cultivar BRS Esmeralda, inoculated with the MAY12 strain and the commercial Azospirillum brasilense inoculant, applied alone or in combination with nitrogen fertilization (N).

\begin{tabular}{|c|c|c|c|c|c|}
\hline \multirow[t]{2}{*}{ Treatments } & \multicolumn{5}{|c|}{ } \\
\hline & $30 / 05$ & $11 / 06$ & $20 / 06$ & $29 / 06$ & $05 / 07$ \\
\hline Commercial Inoculant (T1) & $28.85 \mathrm{c}$ & $26.97 \mathrm{bc}$ & $28.88 \mathrm{~b}$ & $27.05 \mathrm{ab}$ & $26.29 \mathrm{ab}$ \\
\hline MAY12 (T2) & $34.78 \mathrm{bc}$ & $31.49 \mathrm{~b}$ & $28.23 \mathrm{~b}$ & $26.34 \mathrm{~b}$ & $24.45 \mathrm{~b}$ \\
\hline $50 \mathrm{mg} \mathrm{N}(\mathrm{T} 3)$ & $45.89 \mathrm{a}$ & $44.46 \mathrm{ab}$ & $44.21 \mathrm{a}$ & 35.98 a & $34.47 \mathrm{a}$ \\
\hline Commercial Inoculant $+30 \% \mathrm{~N}(\mathrm{~T} 4)$ & $37.76 \mathrm{ab}$ & $36.45 \mathrm{ab}$ & $33.33 \mathrm{~b}$ & $27.88 \mathrm{ab}$ & $30.20 \mathrm{ab}$ \\
\hline Commercial Inoculant $+60 \% \mathrm{~N}(\mathrm{~T} 5)$ & $38.15 \mathrm{ab}$ & $36.06 \mathrm{ab}$ & $32.20 \mathrm{~b}$ & $26.50 \mathrm{~b}$ & $28.17 \mathrm{ab}$ \\
\hline MAY $12+30 \%$ N (T6) & $41.68 \mathrm{ab}$ & $47.75 \mathrm{a}$ & $33.99 \mathrm{~b}$ & $28.85 \mathrm{ab}$ & $27.60 \mathrm{ab}$ \\
\hline MAY $12+60 \%$ of $N(T 7)$ & $40.64 \mathrm{ab}$ & $35.94 \mathrm{ab}$ & $33.05 \mathrm{~b}$ & $27.85 \mathrm{ab}$ & $28.38 \mathrm{ab}$ \\
\hline Absolute control (T8) & $34.01 \mathrm{bc}$ & $19.52 \mathrm{c}$ & $30.78 \mathrm{~b}$ & $28.55 \mathrm{ab}$ & $25.93 \mathrm{ab}$ \\
\hline $\mathrm{CV}(\%)$ & 11.64 & 10.59 & 15.73 & 16.96 & 17.79 \\
\hline
\end{tabular}

Means followed by the same letter do not present significant statistical differences with each other through the Tukey test with a significance level of $5 \%$. 
Table 2 - Means of fresh shoot mass (FSM) and fresh root mass (FRM), dry shoot mass (DSM) and dry root mass (DRM) and total dry mass (TDM) of rice plants, cultivar BRS Esmeralda, inoculated with strain MAY12 and commercial Azospirillum brasilense inoculant, applied alone or in combination with nitrogen fertilization $(\mathrm{N})$.

\begin{tabular}{|c|c|c|c|c|c|}
\hline Treatments & FSM $(g)$ & FRM (g) & $\operatorname{DSM}(\mathrm{g})$ & DRM (g) & TDM (g) \\
\hline Commercial Inoculant (T1) & $10.56 \mathrm{~d}$ & $20.33 \mathrm{~cd}$ & $2.51 \mathrm{c}$ & $2.56 \mathrm{c}$ & $5.08 \mathrm{~d}$ \\
\hline MAY12 (T2) & $12.88 \mathrm{~cd}$ & $31.03 \mathrm{bc}$ & $3.53 \mathrm{bc}$ & $3.36 \mathrm{bc}$ & $6.90 \mathrm{~cd}$ \\
\hline 50mg N (T3) & $22.61 \mathrm{a}$ & $50.73 \mathrm{a}$ & $5.93 \mathrm{a}$ & $5.83 \mathrm{a}$ & $11.76 \mathrm{a}$ \\
\hline Commercial Inoculant $+30 \%$ N (T4) & $16.33 \mathrm{bc}$ & $43.56 \mathrm{ab}$ & $4.51 \mathrm{ab}$ & $3.76 \mathrm{bc}$ & $8.28 \mathrm{bc}$ \\
\hline Commercial Inoculant $+60 \% \mathrm{~N}$ (T5) & $18.33 \mathrm{abc}$ & $43.71 \mathrm{ab}$ & $5.35 \mathrm{a}$ & $4.51 \mathrm{ab}$ & $9.86 \mathrm{ab}$ \\
\hline MAY $12+30 \%$ N (T6) & $19.13 \mathrm{ab}$ & $42.13 \mathrm{ab}$ & $5.30 \mathrm{a}$ & $4.73 \mathrm{ab}$ & $10.03 \mathrm{ab}$ \\
\hline MAY $12+60 \%$ of $N(\mathrm{~T} 7)$ & $19.11 \mathrm{ab}$ & $42.55 \mathrm{ab}$ & $5.58 \mathrm{a}$ & $4.31 \mathrm{ab}$ & $9.90 \mathrm{ab}$ \\
\hline Absolute witness (T8) & $2.11 \mathrm{e}$ & $6.95 \mathrm{~d}$ & $0.43 \mathrm{~d}$ & $0.55 \mathrm{~d}$ & $0.98 \mathrm{e}$ \\
\hline $\mathrm{CV}(\%)$ & 19.84 & 27.42 & 19.44 & 23.05 & 18.54 \\
\hline
\end{tabular}

Means followed by the same letter do not present significant statistical differences with each other through the Tukey test with a significance level of $5 \%$.

of nitrogen fertilizers because its combined use with lower than recommended doses of $\mathrm{N}$ produce the same increase in biomass as the full dose.

Regarding the isolated inoculation treatments, there was no statistical difference between treatments with the commercial inoculant and the MAY12 strain. Treatment containing only the MAY12 strain resulted in an increase of $720 \%$ and $510 \%$ in the production of dry mass of the shoot and roots, respectively, in relation to the absolute control (Table 2). These results showed that the use of the MAY12 strain was as effective as the commercial inoculant in the development of plant biomass.

The total dry mass analyses confirmed the results obtained for the variables fresh and dry mass of shoot and roots in which the highest means were observed in treatments that received nitrogen fertilization (Table 2). Of the treatments that received nitrogen doses along with the inoculation, whether commercial or the MAY12 strain, the commercial inoculant $+30 \% \mathrm{~N}$ was the one that obtained the lowest mean while the others did not differ from each other statistically or from the nitrogen control (Table 2). The mean values for the treatments that did not receive added $\mathrm{N}$ did not statistically differ, and were only higher than that of the absolute control - $604 \%$ higher in the treatment containing the strain MAY12 and $418 \%$ higher in the treatment containing the commercial inoculant (Table 2).

The results of this experiment corroborated several studies in the literature in which the inoculation of PGPBs produced increases in the biomass and yield of rice cultivars. GUIMARÃES et al. (2003) concluded in their greenhouse study with the rice cultivar Guarani that the use of the inoculation of PGPBs promoted growth in factors such as grain production, dry matter and the amount of total N. Increases of $19 \%$ were observed in grain production because of inoculation with strain M130 (Burkholderia brasilensis) and up to 25\% with Herbaspirillum seropedicae strains. KUSS et al. (2008) evaluated the development of rice in soil under growth chamber conditions and reported that inoculation with Azospirillum brasilense was able to increase the production of both fresh and dry mass of three irrigated rice cultivars.

BARBOSA et al. (2016), evaluating the response of rice to different Azospirillum inoculation technologies under greenhouse conditions showed that the increase in biomass of the shoot in one of the cultivars used was significant, achieving an increase of $113 \%$, i.e., more than doubling its mass. This result was obtained using an inoculation performed in the planting groove. However, the inoculation performed by treatment of seeds did not achieve such high values. The authors stated that inoculation in planting grooves is more effective than direct seed inoculation because inoculation via the planting grooves seems to help prevent the toxic effects of chemicals, such as pesticides used in seed treatments, on the bacteria. Thus, a similarity between the form of inoculation

Ciência Rural, v.51, n.12, 2021. 
employed by the authors and the inoculation performed in this study is recognized.

In their experiment of inoculation with PGPBs in rice culture, GUIMARÃES \& BALDANI (2013) reported that the inoculation resulted in positive effects on IR42 and IAC4440 cultivars. There was an increase of $\sim 16 \%$ of nitrogen in the dry shoot mass when compared to the cultivar without inoculation.

Several factors can influence the success of inoculation, such as edaphoclimatic conditions, choice of strain and physiological stage of the inoculation, competitiveness with soil microbiota (REIS, 2007), inoculation techniques, and crop management practices (CÁSSAN \& DIAZ ZORITA, 2016). An important factor for the success of Azospirillum inoculation is the selection of efficient strains (HUNGRIA et al., 2011) because Azospirillum strains differ in their physiology and growth-promoting properties such as the provision of nutrients to plants through BNF and phosphate solubilization and the production of phytohormones. The strain selected for this study was MAY12, which was able to fix atmospheric nitrogen, produce the auxin class phytohormone indole acetic acid (IAA) (SOUZA et al., 2017), and solubilize phosphate (data not yet published) in vitro. Among the 30 bacteria tested for IAA production in the work of SOUZA et al. (2017), MAY12 was the second largest producer of the hormone $1027.68 \mu \mathrm{M}$, producing $378 \%$ and $625 \%$ more IAA than the strains $\mathrm{Sp} 7$ and $\mathrm{Sp} 59$ of $A$. brasilense, respectively, used as the control. According to the authors, the soil environment of the Pantanal, which has low fertility under constant water stress (dry soil and flooded soil), may have favored the genetic adaptations of the strain that presents high IAA production capacity because MAY12 was isolated from the native grass of the Mato Grosso do Sul Pantanal, Hymenachne amplexicualis.

The primary function of IAA is to promote root growth during cell division and meristematic tissue differentiation, which depends on the hormone concentration (SOUZA et al., 2017). Thus, the greater development of grass roots, because of Azospirillum inoculation, increases the area of absorption of water and nutrients, consequently increasing biomass yield and tolerance to environmental stresses such as drought. Inoculation with MAY12 in two forages, in the absence of nitrogen fertilization, resulted in increases for most of the variables tested. Mesosetum chaesea plants inoculated with MAY12 presented greater height and dry mass weight of the shoot and roots compared to the control and those inoculated with the $\mathrm{Sp} 7$ and $\mathrm{Sp} 59$ strains of A. brasilense.
Inoculation of Axonopus purpusii with MAY12 produced an increase in dry shoot mass (SOUZA et al., 2017). In the same study, the phylogenetic analysis of $16 \mathrm{~S}$ and nifH genes were performed with isolated PGPBs, showing that MAY 12 is closely related to the species $A$. brasilense, being considered promising for use in field inoculation experiments.

In the research of GALEANO et al. (2019) corn plants inoculated with MAY12 showed incremental dry mass and total proteins in relation to treatment without inoculation. Moreover, the highest concentration of total proteins was observed in plants inoculated with MAY12 $\left(3628 \mu \mathrm{g} \mathrm{mL}^{-1}\right)$ and commercial inoculant $\left(3545 \mu \mathrm{g} \mathrm{mL}^{-1}\right.$ ) (GALEANO et al., 2019). The inoculation of the MAY12 strain alone in the present study showed positive effects on the development of the BRS Esmeralda rice cultivar, producing mean total dry mass six times greater than that of the control treatment and two times that of the commercial inoculants; although, the mean did not differ statistically from that of the treatment with the commercial inoculant. Furthermore, fertilized and inoculated treatments (with MAY12 or commercial inoculant) presented significantly higher means (eight times) than the absolute control (Table 2). These results, together, reinforced the potential of the MAY12 strain for use in field inoculation experiments and the hypothesis that its use combined with nitrogen fertilization can supply in part the nutrient requirements of the plants.

There was a significant difference between treatments for the plant height variable (Table 3). In the three readings, treatments inoculated with MAY12 (with and without nitrogen fertilization) showed similar results to treatments that received nitrogen fertilizer and the commercial inoculant. The only statistical difference was between the absolute control and the other treatments. Treatments containing $\mathrm{N}$, in general, presented a mean height $\sim 140 \%$ higher than that of the absolute control (Table 3). As regards to treatments inoculated without the addition of $\mathrm{N}$, treatments inoculated with MAY 12 presented height values $\sim 115 \%$ greater than that of the absolute control and statistically similar to the nitrogen control for all readings; however, the mean treatment with the commercial inoculant was not similar to the nitrogen control in the second reading (Table 3). This demonstrates that the inoculation of MAY12 alone was as efficient as the application of the recommended full dose of nitrogen fertilizer to increase plant height.

These data corroborate the study conducted by GUIMARÃES et al. (2015) in his research

Ciência Rural, v.51, n.12, 2021. 
Table 3 - Means of height (H), number of tillers (NT), number of leaves (NL) and root volume (RV) of rice plants, cultivar BRS Esmeralda, inoculated with strain MAY12 and the commercial Azospirillum brasilense inoculant, applied alone or in combination with nitrogen fertilization $(\mathrm{N})$.

\begin{tabular}{|c|c|c|c|c|c|c|c|c|}
\hline \multirow[t]{3}{*}{ Treatments } & \multicolumn{3}{|c|}{-----------------H (cm)---------------- } & \multicolumn{3}{|c|}{----------------NT---------------- } & \multirow[t]{2}{*}{ NL } & \multirow[t]{2}{*}{$\mathrm{RV}\left(\mathrm{cm}^{3}\right)$} \\
\hline & \multicolumn{3}{|c|}{----------Days after sowing---------- } & \multicolumn{3}{|c|}{-------Days after sowing------ } & & \\
\hline & 36 & 57 & 72 & 36 & 57 & 72 & & \\
\hline Commercial Inoculant (T1) & $15.29 \mathrm{a}$ & $15.91 \mathrm{~b}$ & $17.74 \mathrm{~b}$ & $2.75 \mathrm{c}$ & $2.58 \mathrm{c}$ & $2.58 \mathrm{~b}$ & $15.8 \mathrm{c}$ & $21.5 \mathrm{bc}$ \\
\hline MAY12 (T2) & $15.29 \mathrm{a}$ & $17.33 \mathrm{ab}$ & $19.12 \mathrm{ab}$ & $3.66 \mathrm{bc}$ & $3.5 \mathrm{bc}$ & $3.41 \mathrm{ab}$ & $18.0 \mathrm{bc}$ & $35.5 \mathrm{ab}$ \\
\hline $50 \mathrm{mg} \mathrm{N}(\mathrm{T} 3)$ & $16.41 \mathrm{a}$ & $19.70 \mathrm{a}$ & $21.75 \mathrm{ab}$ & $5.0 \mathrm{a}$ & $4.83 \mathrm{a}$ & $4.50 \mathrm{a}$ & $31.3 \mathrm{a}$ & $51.5 \mathrm{a}$ \\
\hline Commercial Inoculant $+30 \% \mathrm{~N}(\mathrm{~T} 4)$ & $15.54 \mathrm{a}$ & $18.91 \mathrm{ab}$ & $23.04 \mathrm{ab}$ & $4.16 \mathrm{ab}$ & $3.75 \mathrm{ab}$ & $3.75 \mathrm{ab}$ & $23.0 \mathrm{~b}$ & $41.0 \mathrm{a}$ \\
\hline Commercial Inoculant $+60 \%$ N (T5) & $16.58 \mathrm{a}$ & $19.12 \mathrm{ab}$ & $20.70 \mathrm{ab}$ & $4.83 \mathrm{ab}$ & $3.91 \mathrm{ab}$ & $3.91 \mathrm{a}$ & $24.1 \mathrm{~b}$ & $45.6 \mathrm{a}$ \\
\hline MAY $12+30 \%$ N (T6) & $16.20 \mathrm{a}$ & $19.33 \mathrm{a}$ & $22.79 \mathrm{ab}$ & $4.91 \mathrm{ab}$ & $4.0 \mathrm{ab}$ & $4.08 \mathrm{a}$ & $24.0 \mathrm{~b}$ & $45.5 \mathrm{a}$ \\
\hline MAY $12+60 \%$ of $N(\mathrm{~T} 7)$ & $16.33 \mathrm{a}$ & $19.37 \mathrm{a}$ & $23.95 \mathrm{a}$ & $4.33 \mathrm{ab}$ & $4.0 \mathrm{ab}$ & $3.91 \mathrm{a}$ & $25.0 \mathrm{ab}$ & $40.0 \mathrm{ab}$ \\
\hline Absolute Control (T8) & $6.41 \mathrm{~b}$ & $8.45 \mathrm{c}$ & $9.45 \mathrm{c}$ & $0.0 \mathrm{~d}$ & $1.0 \mathrm{~d}$ & $1.0 \mathrm{c}$ & $5.6 \mathrm{~d}$ & $7.5 \mathrm{c}$ \\
\hline $\mathrm{CV}(\%)$ & 9.55 & 10.03 & 16.21 & 18.8 & 17.7 & 19.66 & 18.1 & 3.05 \\
\hline
\end{tabular}

Means followed by the same letter do not present significant statistical differences with each other through the Tukey test with a significance level of $5 \%$.

on inoculation in wheat plants, where they used three strains of PGPBs (MTaZ8 from Azospirillum sp., MTh2 from Bacillus sp. and MTb3 from Burkholderia sp.), nitrogen control and commercial inoculant containing the strains ABV5 and ABV6 of A. brasilense. The mean heights of plants inoculated with the strains MTb3, MTaZ8, the commercial inoculant and nitrogen control were the greatest and were statistically similar.

FERREIRA et al. (2014), in their research with six rice cultivars (BRS Bonança, BRS Aimoré, BRS Talento, BRSMG Curinga, Japonês and Bolinha) inoculated with six strains of PGPBs Burkholderia spp. (B7 and B16), Pseudomonas spp. (P18 and P21) and Rhizobium spp. (R65 and R82) and two mixtures containing one strain of each genus, reported a mean increase of $9.3 \%$ in height compared to noninoculated treatments. These results corroborate the results of this study in which the treatments that received inoculation showed better results than those of the absolute control.

For the variable number of tillers, there was a significant difference between treatments that presented performance superior to the absolute control (Table 3). Nitrogen control was the treatment that obtained the best performance. However, from the statistical point of view, it did not differ from treatments that received a combination of inoculant and nitrogen doses. At 72 days after sowing, the treatment containing the MAY12 strain demonstrated a recovery, with numbers statistically equal to the nitrogen control, indicating a positive interaction between the rice crop and the MAY12 strain (Table 3).

A similar result was observed by LEMOS et al. (2013) in their research on inoculation with $A$. brasilense, in combination with nitrogen fertilization in five wheat cultivars (CD 104, CD 108, CD 119, CD 120 and CD 150). They observed a significant effect on the number of tillers, and the treatment that received inoculation combined with nitrogen fertilization presented the highest mean.

The data obtained corroborate with the study by DUTRA et al. (2014) of red rice grown in sandy loam with two treatments: one without inoculant and another inoculated with the endophytic bacterium Gluconacetobacter diazotrophicus of the Embrapa Meio Norte 405 genotype. The authors reported a significant difference in the number of panicles per square meter with an increase of $66.1 \%$ for the inoculated treatment compared to treatment without inoculation.

In relation to the number of leaves, all treatments presented better statistical performance than the absolute control. The treatment that presented the highest mean was nitrogen control; however, from the statistical point of view it was equal only to the inoculated treatment with addition of N - MAY $12+60 \% \mathrm{~N}$ (Table 3). Furthermore, the inoculation of the MAY12 strain alone showed good results for the development of the variable number

Ciência Rural, v.51, n.12, 2021. 
of leaves, obtaining averages similar to treatments inoculated with $\mathrm{N}$ addition (Table 3), showing that the interaction of the MAY12 strain is beneficial for the development of this parameter.

Similar results were obtained by GUIMARÃES et al. (2011a) in their study with Brachiaria decumbens, which showed that the treatment inoculated with Azospirillum sp. strain AZ18 caused a $10 \%$ increase in the number of leaves, compared to the absolute control and compared to the nitrogen control, which reached $83 \%$ of the maximum production observed.

A positive correlation was observed between the MAY12 strain and the variable root mass. The treatment that obtained the highest mean was the nitrogen control; although, it did not statistically differ from inoculated treatments with the addition of $\mathrm{N}$ or the MAY12 treatment (Table 3).

Inoculated treatments with the addition of $\mathrm{N}$ presented values up to six times higher than the absolute control, indicating that inoculation is beneficial for root development (Table 3). Moreover, it was observed that MAY12 alone increased root volume by $373 \%$ in relation to the absolute control. The density of upland rice roots showed a positive correlation with drought tolerance in the work of GUIMARÃES et al. (2011b), demonstrating the importance of root morphology in the tolerance of the plant to water deficiency.

SOUZA et al. (2017) demonstrated that the inoculation of MAY12 in Mesosetum chasea grass plants produced an $88.3 \%$ increase in root volume compared to the control without inoculation. Similar results were observed in the study by MARQUES et al. (2021) in which corn plants inoculated with $A$. brasilense increased root volume by an average of 40 and $47 \%$ under irrigation and water deficit conditions, respectively, when compared to control without inoculation.

\section{CONCLUSION}

Inoculation of the rice cultivar BRS Esmeralda with the strain MAY12 of Azospirillum spp. demonstrated that it is beneficial to the plants in all the parameters analyzed. The MAY12 strain confirmed to be promising in the partial reduction of nitrogen fertilizers in the cultivation of upland rice.

\section{ACKNOWLEDGEMENTS}

To Conselho Nacional de Desenvolvimento Científico e Tecnológico (CNPq) for the Scientific Initiation Fellowships grant and Fundação de Apoio ao Desenvolvimento do Ensino, Ciência e Tecnologia do Estado de Mato Grosso do Sul (FUNDECT) for the promotion of the research project.

\section{DECLARATION OF CONFLICT OF INTEREST}

The authors declare no conflict of interest. The founding sponsors had no role in the design of the study; in the collection, analyses, or interpretation of data; in the writing of the manuscript, and in the decision to publish the results.

\section{AUTHORS' CONTRIBUTIONS}

The authors contributed equally to the manuscript.

\section{REFERENCES}

ARANTES, J. T. Como produzir arroz com baixo consumo de água. 2013. Available from: <http://agencia.fapesp.br/comoproduzir-arroz-com-baixo-consumo-de-agua/17238/>. Accessed in: Jun. 04, 2020.

BARBOSA, A.M. et al. Response of rice cultivars to forms of inoculation with Azospirillum brasilense. Acta Iguazu, Cascavel, v.5, n.3, p. 99-110, 2016. Available from: <http://e-revista.unioeste.br/index. php/actaiguazu/article/view/15943/10840>. Accessed: Mar. 18, 2019.

BASHAN, Y. et al. How the plant growth-promoting bacterium Azospirillum promotes plant growth - a critical assessment. Adv. Agron. v.108, p.77-136, 2010. Available from: <https://www. sciencedirect.com/science/article/pii/S0065211310080028>. Accessed: Sept. 01, 2020. doi: 10.1016/S0065-2113(10)08002-8.

BONFIM-SILVA E. M. et al. Initial development of grasses under water stress. Revista Caatinga, v.24, n.2, p.180-186, 2011. Available from: <https://periodicos.ufersa.edu.br/index.php/ caatinga/article/view/1871/4729>. Accessed: Mar. 31, 2019.

CABANGON, R. J. et al. Chlorophyll meter-based nitrogen management of rice grown under alternate wetting and drying irrigation. Field Crops Research, v.121, n.1, p.136-146, 2011. Available from: <https://www.sciencedirect.com/science/article/ pii/S0378429010003163>. Accessed: Aug. 10, 2020. doi:10.1016/j. fcr.2010.12.002

CARVALHO, M. A. de F. et al. Utilização do Clorofilômetro para Racionalização da Adubação Nitrogenada nas Culturas do Arroz e do Feijoeiro. Comunicado técnico 205, 2012. ISSN 1678-961X. Available from: $<$ https://ainfo.cnptia.embrapa.br/digital/bitstream/ item/57145/1/ct205.pdf>. Accessed: Aug. 11, 2020.

CASSÁN, F. et al. Azospirillum spp. in current agriculture: from the laboratory to the field. Soil Biology and Biochemistry, v.103, p.117-130, 2016. Available from: <https://www.sciencedirect. com/science/article/pii/S0038071716302000>. Accessed: Dec. 20, 2020. doi:10.1016/j.soilbio.2016.08.020.

CASTRO, A. P. de et al. BRS Esmeralda: Cultivar de arroz de terras altas com elevada produtividade e maior tolerância à seca. Comunicado Técnico 215, 2014. ISSN 1678-961X. Available from: $<$ https:/ainfo.cnptia.embrapa.br/digital/bitstream/item/100144/1/ comunicadotecnico-215.pdf $>$. Accessed: Sept. 10, 2020. 
CONAB - Companhia nacional de abastecimento. Acompanhamento da safra brasileira de grãos. v.6 - SAFRA 2018/19 - n.6 - Sexto levantamento. Brasília, p. 1-145. 2019. ISSN 2318-68-52. Available in: <https://www.conab.gov.br/info-agro/ safras/graos/boletim-da-safra-de-graos?start $=20>$. Accessed: Feb. 10, 2019.

DUTRA, L. M. F. et al. Inoculação de Gluconacetobacter diazotrophicus e seu efeito no desenvolvimento de plantas de arroz vermelho. J. Biol. \& Pharm. and Agricult. Manage., v.10, n.4, p.86-101, 2014. ISSN 1983-4209. Available from: <http:// revista.uepb.edu.br/index.php/biofarm/article/view/2629/1399>. Accessed: Mar. 20, 2019.

EMPRESA BRASILEIRA DE PESQUISA AGROPECUARIA EMBRAPA. Sistema brasileiro de classificação de solos. 2.ed. Rio de Janeiro, Embrapa Solos, 306p., 2006. Available from: $<$ https://www.agrolink.com.br/downloads/sistema-brasileiro-declassificacao-dos-solos2006.pdf>. Accessed: Mar. 15, 2019.

FAGERIA, N. K. et al. Enhancing nitrogen use efficiency in crop plants. Advances in Agronomy, v.88, p.97-185, 2005. Available from: <https://www.sciencedirect.com/science/article/ pii/S0065211305880046>. Accessed: Aug. 12, 2020. doi: 10.1016/ S0065-2113(05)88004-6.

FAGERIA, N. K. et al. Nitrogen use efficiency in upland rice genotypes. Journal of Plant Nutrition, v.33, p.1696-1711, 2010 Available from: $<\mathrm{http}: / / \mathrm{dx}$.doi.org/10.1080/01904167.2010.49689 2>. Accessed: Aug. 09, 2020. doi: 10.1080/01904167.2010.496892.

FERREIRA, D. F. Sisvar: Um sistema computacional de análise estatística. Ciência e Agrotecnologia, v. 35, n. 6, 2011. Available from: <https://www.scielo.br/pdf/cagro/v35n6/ a01v35n6.pdf>. Accessed: Mar. 03, 2019. doi: 10.1590/S141370542011000600001 .

FERREIRA, E. P. B. et al. Growth of rice cultivars (Oryza sativa L.) as affected by inoculation with plant growth-promoting bacteria. Bioscience Journal, v.30, n.3, p.655-665, 2014. Available from: $<$ http://www.seer.ufu.br/index.php/biosciencejournal/article/ view/18043/13923>. Accessed: Feb. 15, 2019.

FERREIRA, J.S. et al. Seleção de veículos para preparo de inoculante com bactérias diazotróficas para arroz inundado. Agronomia, v.37, n.2, p.06 - 12, 2003. Available from: <https:// www.researchgate.net/publication/242228369_SELECAO DE VEICULOS PARA O PREPARO DE INOCULANTE COM_BACTERIAS_DIAZZOTROFICAS_PARA_ARROZ_ INUNDADO $>$. Accessed: Feb. 03, 2019.

FUKAMI, J. et al. Accessing inoculation methods of maize and wheat with Azospirillum brasilense. AMB Express v.6, p.1-13, 2016. Available from: <https://ainfo.cnptia.embrapa.br/digital/ bitstream/item/140653/1/13568-2015-Article-171.pdf > . Accessed: Aug. 02, 2020. doi: 10.1186/s13568-015-0171-y.

FUKAMI, J. et al. Azospirillum: benefits that go far beyond biological nitrogen fixation. AMB Express, 8, p.73, 2018. Available from: <https://ainfo.cnptia.embrapa.br/digital/bitstream/ item/189968/1/Fukami-73.pdf>. Accessed: May, 20, 2020 doi:10.1186/s13568-018-0608-1.

GALEANO, R.M.S. et al. Initial development and quantification of corn proteins inoculated with new strains of Azospirillum brasilense. Journal of Neotropical Agriculture. v6, n2, 2019. ISSN 2358-
6303. Available from: <https://periodicosonline.uems.br/index. php/agrineo/article/view/2613/2854>. Accessed: Mar. 13, 2020.

GUIMARÃES, C. M. et al. Sistema radicular do arroz de terras altas sob deficiência hídrica. Pesquisa Agropecuária Tropical, v.41, n.1, p.126-134, 2011b. Available from: <https://www. revistas.ufg.br/pat/article/view/8460>. Accessed: Mar. 11, 2020. doi:10.5216/pat.v41i1.8460.

GUIMARÃES, S.L. et al. Crescimento e Desenvolvimento inicial de Brachiaria decumbens inoculada com Azospirillum spp. Enciclopédia biosfera, Centro Científico Conhecer - Goiânia, v.7, n.13; 2011a. Available from: <https://conhecer.org.br/ojs/index. php/biosfera/article/view/4116>. Accessed: Jul. 13, 2019.

GUIMARÃES, S. L. et al. Efeito da inoculação de bactérias diazotróficas endofíticas em arroz de sequeiro. Revista Agronomia, v.37, n.2, p.25-30, 2003. Available from: <http://www.ia.ufrrj.br/ ra/artigos/38_54.pdf $>$. Accessed: Mar. 25, 2019.

GUIMARÃES, S.L. et al. Bactérias diazotróficas e adubação nitrogenada em cultivares de arroz. Revista Caatinga, v.23, n.4, p.3239, 2010. Available from: <https://periodicos.ufersa.edu.br/index.php/ caatinga/article/view/1771/4613>. Accessed: Aug. 22, 2019.

GUIMARÃES, S. L. et al. Produção de arroz inoculado com bactérias diazotróficas marcadas com resistência induzida ao antibiótico estreptomicina. Embrapa Agrobiologia-Artigo em periódico indexado (ALICE), 2013. Available from: <http://doi.editoracubo. com.br/10.4322/rca.2013.020>. Accessed: Mar. 18, 2019.

GUIMARÃES, S.L. et al. Inoculação de bactérias diazotróficas em plantas de trigo cultivado no Sul de Mato Grosso. Cerrado Agrociências, n.6, p.45-54, 2015. ISSN 2178-7662. Available from: $<$ https://revistas.unipam.edu.br/index.php/cerradoagrociencias/ issue $/$ view/76/Edi\%C3\%A7\%C3\%A3o\%20completa2015>. Accessed: Apr. 17, 2019.

HUNGRIA, M. Inoculação com Azospirillum brasilense: inovação em rendimento a baixo custo. Documentos 325. Embrapa Soja, Londrina-PR. 2011. ISSN 1516-781X. Available from: $<$ https://ainfo.cnptia.embrapa.br/digital/bitstream/item/29560/1/ DOC325.2011.pdf $>$. Accessed: Mar. 23, 2019.

HUNGRIA, M. et al. Inoculation with selected strains of Azospirillum brasilense and A. lipoferum improves yields of maize and wheat in Brazil. Plant and Soil, v.331, p.413-425, 2010. Available from: <http://dx.doi.org/10.1007/s11104-009-0262-0>. Accessed: Jun. 18, 2019. doi: 10.1007/s11104-009-0262-0.

JARDIM, T. M. et al. Uso Combinado de Inoculantes de Bactérias Diazotróficas e Adubação Nitrogenada Mineral no Cultivo de Arroz Irrigado. Circular técnica 198, Pelotas: Embrapa Clima Temperado, 25p., 2018. ISSN 1516-8832. Available from: $<$ http://ainfo.cnptia.embrapa.br/digital/bitstream/item/189468/1/ CIRCULAR-198.pdf>. Accessed: Jun. 20, 2019.

KUMAR, V. et al. Direct seeding of rice: Recent developments and future research needs. Advances in Agronomy, v.111, p.297- 413, 2011. Available from: <https://www.sciencedirect.com/science/ article/pii/B9780123876898000011>. Accessed: Feb. 17, 2019. doi: 10.1016/B978-0-12-387689-8.00001-1.

KUSS, A.V. et al. Inoculação de bactérias diazotróficas e desenvolvimento de plântulas de arroz irrigado em solo e câmara de crescimento. Revista da FZVA, v.15, n.1, p.90-102 2008. Available 
from: <https://www.researchgate.net/publication/278000640 Inoculacao de Bacterias Diazotroficas e Desenvolvimento de_Plantulas_de_Arroz_Irrigado_em_Solo_e_Camara_de_ Crescimento>. Accessed: Mar. 14, 2019.

LEMOS, J.M. Response of wheat cultivars to inoculation of seeds with Azospirillum brasilense and to nitrogenous fertilizer side dressed to the plants. Científica, v.41, n.2, p.189-198, 2013. Available from: <http://cientifica.org.br/index.php/ cientifica/article/view/429>. Accessed: Jul. 13, 2019. doi: 10.15361/1984-5529.2013v41n2p189-198.

MARQUES, D.M. et al. Gas Exchange, Root Morphology and Nutrients in Maize Plants Inoculated with Azospirillum brasilense Cultivated Under Two Water Conditions. Braz. arch. biol. technol. v.64: e21190580, 2021. Available from: <https:/www.scielo.br/ pdf/babt/v64/1516-8913-babt-64-e21190580.pdf >. Accessed: Apr. 27, 2021. doi: 10.1590/1678-4324-2021190580.

REIS, V. M. Uso de bactérias fixadoras de nitrogênio como inoculante para aplicação em gramíneas. Documentos 232, Seropédica: Embrapa Agrobiologia, 22 p.2007. ISSN $1517-$
8498. Available from: <https:/www.infoteca.cnptia.embrapa.br/ bitstream/doc/629377/1/doc232.pdf>. Accessed: Mar. 27, 2019.

RODRIGUES NETO, J. et al. Meio simples para isolamento e cultivo de Xanthomonas campestris pv. citri tipo B. Summa Phytopathologica, v.12, p.16, 1986. Link: <https://www.scielo. br/scielo.php? script $=$ sci nlinks \&ref $=000090 \&$ pid $=S 0102$ $0536200300010000900020 \& \operatorname{lng}=\mathrm{pt}>$.

SILVA, O. F. Árvore do conhecimento: arroz. Estatística de produção. 2014. Available in: <http:// www.agencia.cnptia.embrapa.br/gestor/arroz/arvore/ CONT000fe7457q102wx5eo07qw4xezy8czjj.html>. Accessed: Jun. 04, 2020

SOUZA, M.S.T. et al. Azospirillum spp. from native forage grasses in Brazilian Pantanal floodplain: biodiversity and plant growth promotion potential. World Journal of Microbiology \& Biotechnology, v.33, n.4 p.81, 2017. Available from: <https:// ainfo.cnptia.embrapa.br/digital/bitstream/item/165317/1 Paulo-Ivan.pdf>. Accessed: Aug. 14, 2020. doi: 10.1007/ s11274-017-2251-4. 